\title{
Extrinsic allergic alveolitis in the tobacco industry
}

\author{
M S HUUSKONEN,' K HUSMAN,' J JÄRVISALO,' O KORHONEN,' M KOTIMAA,' \\ T KUUSELA,' H NORDMAN,' A ZITTING, ${ }^{1}$ AND R MÄNTYJÄRVI²
}

From the Institute of Occupational Health, Haartmaninkatu 1, SF-00290 Helsinki 29, and the Department of Clinical Microbiology, University of Kuopio, Kuopio, Finland

ABSTRACT A total of 57 subjects who had been exposed to mould dust in the tobacco industry were studied. Their working environment showed exposure to spores of different moulds, and 29 subjects $(51 \%)$ showed antibodies against one or more of the microbes. Fifteen $(26 \%)$ had work related respiratory symptoms. Eight $(14 \%)$ showed slight radiographic pulmonary fibrosis. Spirometry showed a tendency toward restriction and obstruction, especially in small airways. Diffusion capacity was decreased in $18 \%$ of the workers. Three clinical cases of typical allergic alveolitis were also found. All this suggests that exposure of spores of different moulds (especially Aspergillus fumigatus) in the manufacture of tobacco products may induce symptoms and signs relating to extrinsic allergic alveolitis.

Extrinsic allergic alveolitis ${ }^{1}$ is a form of hypersensitivity in which the allergic reaction takes place in the peripheral parts of the bronchopulmonary tree and gives rise to a defect in gas exchange. Various biological dusts with particles small enough to penetrate into the alveoli can act as allergens. Exposure stimulates the formation of circulating antibodies to the offending allergens.

About 20 different alveolitides have been reported, ${ }^{2}$ most of them occupational diseases. Although raw tobacco dust is a known sensitising agent, ${ }^{2}$ no reports have been published concerning alveolitis in the tobacco manufacturing industry. Some workers in the industry had work related respiratory symptoms and lung fibrosis. Therefore the aim of the present study was to determine the relation between occupational exposure to raw tobacco dust and the clinical, radiological, functional, and immunological findings among tobacco workers in a Finnish factory.

\section{Exposure and aerobiology}

In the factory the raw tobacco undergoes several stages of processing: (1) opening, (2) wetting, (3) roasting, (4) cutting, (5) blending, (6) making, (7) packing, and (8) storage. Stages 1 and 2 take place on the first floor of the factory and are separate from

Received 13 November 1982

Accepted 17 January 1983 stages 3-7 which take place in the big shop on the second floor.

The aerobiological investigation of moulds and actinomycetes took place in spring 1981. Spore sampling was carried out with an Andersen sampler (model 10-800, Andersen 2000 Inc, Georgia, USA) on Petri dishes. ${ }^{3}$ Samples were taken from each of the work stages at the factory. After exposure, the culture media were incubated at room temperature (sodium-chloride-malt extract media for Aspergillus umbrosus and Hagen media for other mesophilic moulds) at $40^{\circ} \mathrm{C}$ (Hagen media for thermotolerant moulds) and at $55^{\circ} \mathrm{C}$ (half strength Nutrient media for thermophilic actinomycetes). When a good growth was seen, the colonies were counted and analysed microbiologically and the number of spores in the air of the working environment was estimated.

The numbers and types of different moulds and actinomycetes vary in raw tobacco, which is imported from more than 10 countries. Spore exposure consists mainly of the spores of different Aspergillus species. The exposure is greatest at the begining of production (stages 1-2), although workers are exposed to mould dust through the whole production line (stages 3-7). The main mould species or genera were Aspergillus sp, A umbrosus, A fumigatus, and Penicillium sp. Small numbers of spores of Thermoactinomyces vulgaris were also found. Men in the workshop are exposed to high peak concentrations during production disturbances, and even the office workers are exposed to small amounts of spore dust during their visits to the production area. 


\section{Subjects and methods}

During February and March 1981, 57 subjects (29 men and 28 women) were examined. Nine were subjected to the highest exposure, which results from opening raw tobacco bales (exposure group 1, operational stages 1-2); 25 were continuously exposed in production (exposure group 2, operational stages 3-7); 13 from the maintenance workshop were temporarily exposed heavily during production disturbances (exposure group 3); and 10 office workers formed a group with the mildest exposure (exposure group 4). Table 1 summarises the clinical data, occupational exposure, and smoking habits of the different groups.

Smokers were defined as individuals who habitually carried cigarettes or pipe tobacco for their own use, whereas ex-smokers had given up smoking at least one year earlier. ${ }^{4}$

The clinical examinations were performed by the same physician (MSH) and included a standardised questionnaire on respiratory symptoms ${ }^{5}$ and a medical history. It also included an appraisal of the overall health status, auscultation, and recording of crepitations in the chest. Crepitations were recorded as non-musical explosive sounds during inspiration. ${ }^{6}$

The radiographic examinations included two full size posteroanterior films. The radiographic technique has been described in detail by Zitting et al. ${ }^{7}$ The chest films were all examined by three of us (TK, AZ and MSH) using the ILO International Classification of Pneumoconioses. The films were read independently with no knowledge of the subjects. If the assessments did not agree the films were reviewed by the readers together; the score determined jointly was then used as the classification.
Lung function tests included dynamic spirometry and diffusion capacity. A pneumotachygraph spirometry (ME 2 PD, Medikro, Finland) was used to measure the forced vital capacity (FVC), the forced expiratory volume in one second $\left(\mathrm{FEV}_{1}\right)$ and maximal mid-expiratory flow (MMEF). FEV\% was calculated $(100 \times \mathrm{FEV} / \mathrm{FVC})$. The carbon monoxide diffusion capacity ( $\mathrm{DL}_{\mathrm{CO}}$ ) was measured by the method of Cotes ${ }^{9}$ with a Transfer Test-apparatus (Morgan, England).

The activities of serum angiotensin convertase were determined by the method of Chiknas. ${ }^{10}$ The method gave results which correlated well $(r=0.98$, $\mathrm{n}=27)$ with those obtained with the spectrophotometric method of Lieberman ${ }^{11}$ but which were about $20 \%$ lower than those obtained with the spectrophotometric method. The day to day variation coefficient estimated with three pools of hospital patients gave a value of $9.3 \%-13.4 \%$ at an activity level around $20 \mathrm{U} / 1\left(\mu \mathrm{mol} \times \mathrm{min}^{-1} \times \mathrm{1}^{-1}\right.$ of hippurate liberated).

Serum was tested for antibodies against Micropolyspora faeni, Th vulgaris, $A$ fumigatus, and $A$ umbrosus. ${ }^{12}$ Cellular antigens were used, and enzyme linked immunosorbent assays (ELISA) were performed as described previously. ${ }^{13}$ Serum antibody titres were expressed as the negative logarithm of the serum dilution that gave an absorbance of $0 \cdot 5$. The background binding of a negative serum pool was substrated from the titres. Serum titres exceeding the mean of the negative serum determinations by three standard deviations were considered positive and those between 2.5 and 2.9 standard deviations above the negative serum were considered weakly positive.

The chi-square test was used for the statistical

Table 1 Occupational and clinical data for the different exposure groups

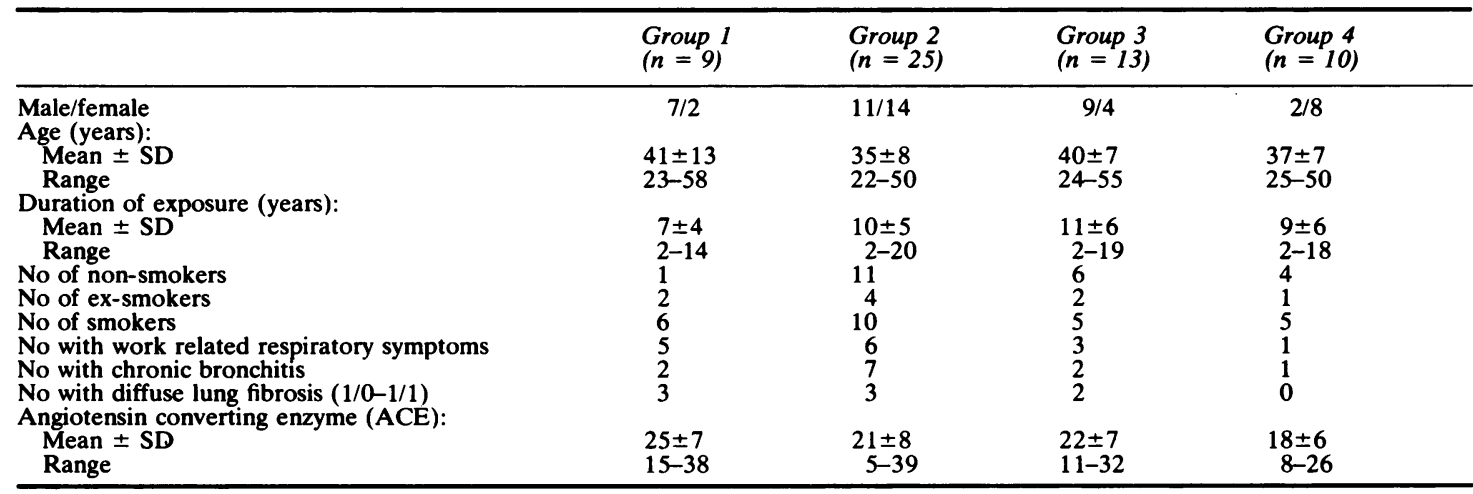

Group 1 = Nine workers with highest exposure; operational stages 1-2.

Group 2 = Twenty five workers continuously exposed in production; operational stages 3-7.

Group $3=$ Thirteen workers temporarily heavily exposed during production disturbances.

Group $4=$ Ten office workers. 
analyses. For comparisons where the frequencies were low, Fisher's exact probability test was used. Student's $t$ test was used for comparison of the activities of the angiotensin convertase in the serum of the study groups.

\section{Results}

The results of hygienic measurements made at the different operational stages and in the ventilation unit are presented in table 2 .

\section{SYMPTOMS AND SIGNS}

Fifteen of the 57 subjects $(26 \%)$ had "tightness" of the chest, or cough or breathlessness, or a combination of these, and these symptoms were work related, worsening during the day and improving or vanishing at weekends. Three of these 15 were non-smokers. All three non-smokers experienced worsening of symptoms four to eight hours after starting work, as did four of the 12 ex-smokers and smokers. All those who experienced symptoms after four to eight hours' work worked in manufacturing (three in group 1, three in group 2, and one in group 3 ). Eight other subjects (four smokers and four ex-smokers) had insidious symptoms of the same type that were alleviated during holidays. Two were. in exposure group 1, three in group 2, two in group 3 , and one in group 4 . Neither the medical history nor a clinical examination of these 15 subjects provided any explanation for the symptoms other than work exposure and smoking.

Thirteen of the 57 subjects had symptoms of chronic bronchitis, defined as a cough and production of phlegm for three months a year for a period of at least two years. The findings in the different exposure groups are given in table 1 . Three of the 22 non-smokers had chronic bronchitis. They had worked for 10,14 , and 19 years, respectively, in manufacturing. The medical histories of these three subjects provided no explanation for the chronic bronchitis other than dust exposure.

Two subjects belonging to group 1 showed crepitations in auscultation. Both were smokers.

\section{RADIOGRAPHIC FINDINGS}

Pulmonary fibrosis $(\geqslant 1 / 0)$ was found in the lower or mid-zones in $14 \%(8 / 57)$ of the subjects. Fibrosis was mild in profusion ( $1 / 0$ for three workers and $1 / 1$ for five workers) and opacities were irregular ( $\mathrm{s} / \mathrm{t}$ or $\mathrm{t} / \mathrm{s}$ ). Table 1 shows the presence of lung fibrosis in different exposure groups. The average exposure time of the eight subjects with radiological lung fibrosis was 13 years (3-21). One of the eight subjects was a non-smoker and had been exposed for 16 years. The clinical data of the subjects with lung fibrosis are shown in detail in table 3.

Two of the tobacco workers with lung fibrosis (1/

Table 2 Total number of spores from different groups of micro-organisms per cubic metre of air taken at different operational stages of the process and at a central ventilation unit

\begin{tabular}{|c|c|c|c|c|}
\hline $\begin{array}{l}\text { Operational stages of the process }(1-7) \\
\text { and a central ventilation unit }\end{array}$ & $\begin{array}{l}\text { Total No of } \\
\text { spores } / m^{3} \text { air }\end{array}$ & $\begin{array}{l}\text { No of mesophilic } \\
\text { spores } / \mathrm{m}^{3} \text { air }\end{array}$ & $\begin{array}{l}\text { No of thermotolerant } \\
\text { spores } / m^{3} \text { air }\end{array}$ & $\begin{array}{l}\text { No of thermophilic } \\
\text { spores } / \mathrm{m}^{3} \text { air }\end{array}$ \\
\hline $\begin{array}{l}\text { Opening and wetting of raw } \\
\text { tobacco (1-2) } \\
\text { Roasting (3) } \\
\text { Cutting (4) } \\
\text { Blending (5) } \\
\text { Making (6) } \\
\text { Packing (7) } \\
\text { Central ventilation unit }\end{array}$ & $\begin{array}{r}10600 \\
2300 \\
5000 \\
1500 \\
4900 \\
3500 \\
600\end{array}$ & $\begin{array}{r}10400 \\
2300 \\
4900 \\
1400 \\
4600 \\
3500 \\
20\end{array}$ & $\begin{array}{r}130 \\
20 \\
20 \\
50 \\
220 \\
20 \\
140\end{array}$ & $\begin{array}{r}40 \\
20 \\
50 \\
70 \\
70 \\
20 \\
410\end{array}$ \\
\hline
\end{tabular}

Table 3 Clinical data of patients with lung fibrosis in chest $x$ rays

\begin{tabular}{|c|c|c|c|c|c|c|c|c|c|c|}
\hline $\begin{array}{l}\text { Sex and age } \\
\text { (years) }\end{array}$ & $\begin{array}{l}\text { Presence of } \\
\text { work related } \\
\text { symptoms }\end{array}$ & $\begin{array}{l}\text { Smoking } \\
\text { habits }\end{array}$ & $\begin{array}{l}\text { Exposure } \\
\text { (years) }\end{array}$ & $\begin{array}{l}\text { Chest } x \text { ray } \\
\text { findings }\end{array}$ & Antibody titre & $\begin{array}{l}\text { Lung } \\
\text { functions } \\
D L_{C O}\end{array}$ & $F V C$ & $F F E V_{1}$ & $M M E F$ & Others \\
\hline M 48 & + & Ex-smoker & 20 & $\mathrm{t} / \mathrm{s} 1 / 1$ & A fumigatus 0.7 & 68 & 88 & 55 & 22 & - \\
\hline M 58 & + & Smoker & 9 & $\mathrm{~s} / \mathrm{t} 1 / 1$ & A fumigatus 0.1 & 69 & 89 & 88 & 60 & - \\
\hline M 39 & - & Ex-smoker & 16 & $\mathrm{~s} / \mathrm{t} 1 / 1$ & - & 98 & 96 & $9 \overline{7}$ & 99 & - \\
\hline M 41 & + & Ex-smoker & 8 & $\mathrm{~s} / \mathrm{t} 1 / 1$ & - & 76 & 100 & 88 & 105 & - \\
\hline M 39 & - & Smoker & 2 & $s / t 1 / 0$ & $\begin{array}{ll}\text { Th vulgaris } & 0.6 \\
M \text { faeni } & 0.2\end{array}$ & 96 & 100 & 93 & 66 & $\begin{array}{l}\text { Quartz exposure } \\
\text { (1964-9) }\end{array}$ \\
\hline M 56 & + & Non-smoker & 16 & $\mathrm{~s} / \mathrm{t} 1 / 1$ & $A$ fumigatus 1.0 & 106 & 93 & 86 & 43 & - \\
\hline M 58 & + & Smoker & 7 & $s / t 1 / 0$ & $\begin{array}{ll}\text { A fumigatus } & 1 \cdot 6 \\
\text { A umbrosus } & 0 \cdot 4 \\
M \text { faeni } & 0 \cdot 1 \\
\text { Th vulgaris } & 0 \cdot 1\end{array}$ & 68 & 82 & 90 & 97 & $\begin{array}{l}\text { A farmer } \\
(1949-60)\end{array}$ \\
\hline F 49 & - & Smoker & 21 & $\mathrm{~s} / \mathrm{t} 1 / 0$ & A fumigatus 0.8 & 48 & 101 & 85 & 46 & - \\
\hline
\end{tabular}


$0-1 / 1)$ had been exposed to fibrogenic dust before the present exposure. Eighteen years ago, one worker had been exposed to silica dust for five years as a truck driver in a ceramics factory. The present heavy exposure caused by opening raw tobacco bales had lasted three years. The other man had been a farmer in 1949-60 and had been exposed to mouldy hay; in his present job he had been opening raw tobacco bales for seven years.

RESPIRATORY PHYSIOLOGICAL MEASUREMENTS Fifty two of the 57 workers $(91 \%)$ who participated in the respiratory physiological measurements had normal FVC ( $\geqslant 80 \%$ of the predicted). In four $(7 \%)$ the $\mathrm{FEV}$, was decreased ( $<80 \%$ of the predicted). In 13 workers $(23 \%)$ the MMEF was decreased ( $<70 \%$ of the predicted) whereas the $\mathrm{DL}_{\mathrm{CO}}$ was decreased ( $<80 \%$ of the predicted) in 10 subjects $(18 \%)$. The results of respiratory physiological measurements in the different exposure groups are presented in table 4 . The lung functions of the subjects were also grouped according to smoking habits and the profusion of radiograph opacities (table $5)$. In addition to opacities the presence of antibodies was evaluated, and the different groups either with or without lung fibrosis or with different

Table 4 Respiratory physiological measurements in different exposure groups

\begin{tabular}{|c|c|c|c|c|}
\hline & $\begin{array}{l}\text { Group } 1 \\
(n=9)\end{array}$ & $\begin{array}{l}\text { Group } 2 \\
(n=25)\end{array}$ & $\begin{array}{l}\text { Group } 3 \\
(n=13)\end{array}$ & $\begin{array}{l}\text { Group } 4 \\
(n=10)\end{array}$ \\
\hline \multicolumn{5}{|l|}{ FVC: } \\
\hline $\begin{array}{l}\text { Mean } \pm S D \\
\text { Range } \\
\text { No of decreased } \\
\text { FEV }\end{array}$ & $\begin{array}{l}93 \pm 6 \\
76-102 \\
1\end{array}$ & $\begin{array}{l}94 \pm 19 \\
69-126 \\
2\end{array}$ & $\begin{array}{l}97 \pm 14 \\
73-122 \\
1\end{array}$ & $\begin{array}{l}96 \pm 14 \\
62-118 \\
1\end{array}$ \\
\hline $\begin{array}{l}\text { Mean } \pm \text { SD } \\
\text { Range } \\
\text { No of decreased } \\
\text { MMEF: }\end{array}$ & $\begin{array}{l}95 \pm 10 \\
87-119 \\
0\end{array}$ & $\begin{array}{l}98 \pm 11 \\
83-125 \\
0\end{array}$ & $\begin{array}{l}91 \pm 22 \\
55-123 \\
3\end{array}$ & $\begin{array}{l}93 \pm 11 \\
69-102 \\
1\end{array}$ \\
\hline $\begin{array}{l}\text { Mean } \pm S D \\
\text { Range } \\
\text { No of decreased }\end{array}$ & $\begin{array}{l}91 \pm 29 \\
60-153 \\
3\end{array}$ & $\begin{array}{l}101 \pm 27 \\
46-173 \\
4\end{array}$ & $\begin{array}{l}84 \pm 38 \\
22-129 \\
4\end{array}$ & $\begin{array}{l}83 \pm 20 \\
42-115 \\
2\end{array}$ \\
\hline $\begin{array}{l}\text { MLC: } \\
\text { Mean } \pm \text { SD } \\
\text { Range } \\
\text { No of decreased }\end{array}$ & $\begin{array}{l}93 \pm 17 \\
68-133 \\
2\end{array}$ & $\begin{array}{l}93 \pm 17 \\
48-127 \\
5\end{array}$ & $\begin{array}{l}94 \pm 13 \\
67-116 \\
2\end{array}$ & $\begin{array}{l}94 \pm 15 \\
79-127 \\
1\end{array}$ \\
\hline
\end{tabular}

Groups as in table 1 .

Table 5 Respiratory physiological measurements of tobacco workers according to smoking habit and profusion of pulmonary radiographic opacities

\begin{tabular}{|c|c|c|c|c|c|c|c|c|}
\hline Non-smokers: & \multicolumn{2}{|c|}{$\begin{array}{l}F V C \\
\text { profusion } \\
\text { category } \\
(<1 / 0 \geqslant 1 / 0)\end{array}$} & \multicolumn{2}{|c|}{$\begin{array}{l}\text { FEV } \\
\text { profuision } \\
\text { category } \\
(<1 / 0 \geqslant 1 / 0)\end{array}$} & \multicolumn{2}{|c|}{$\begin{array}{l}M M E F \\
\text { profusion } \\
\text { category } \\
(<1 / 0 \geqslant 1 / 0)\end{array}$} & \multicolumn{2}{|c|}{$\begin{array}{l}D L_{C O} \\
\text { profusion } \\
\text { category } \\
(<1 / 0 \geqslant 1 / 0)\end{array}$} \\
\hline $\begin{array}{l}\text { No } \\
\text { Mean } \pm \text { SD }\end{array}$ & $\begin{array}{l}21 \\
98 \pm 11\end{array}$ & $\begin{array}{l}1 \\
93 \pm 0\end{array}$ & $\begin{array}{l}21 \\
97 \pm 12\end{array}$ & $\begin{array}{l}1 \\
87 \pm 0\end{array}$ & $\begin{array}{l}21 \\
98 \pm 22\end{array}$ & $\begin{array}{l}1 \\
43 \pm 0\end{array}$ & $\begin{array}{l}21 \\
94 \pm 9\end{array}$ & $\begin{array}{l}1 \\
106 \pm 0\end{array}$ \\
\hline $\begin{array}{l}\text { Ex-smokers: } \\
\text { No } \\
\text { Mean } \pm \text { SD }\end{array}$ & $\begin{array}{l}5 \\
90 \pm 17\end{array}$ & $\begin{array}{l}4 \\
96 \pm 6\end{array}$ & $\begin{array}{l}5 \\
95 \pm 16\end{array}$ & $\begin{array}{l}4 \\
83 \pm 19\end{array}$ & $\begin{array}{l}5 \\
106 \pm 26\end{array}$ & $\begin{array}{l}4 \\
730 \pm 38\end{array}$ & $\begin{array}{l}5 \\
110 \pm 20\end{array}$ & $\begin{array}{l}4 \\
85 \pm 15\end{array}$ \\
\hline $\begin{array}{l}\text { Smokers: } \\
\text { No } \\
\text { Mean } \pm \text { SD }\end{array}$ & $\begin{array}{l}23 \\
97 \pm 12\end{array}$ & $\begin{array}{l}3 \\
69 \pm 7\end{array}$ & $\begin{array}{l}23 \\
96 \pm 15\end{array}$ & $\begin{array}{l}3 \\
88 \pm 3\end{array}$ & $\begin{array}{l}23 \\
93 \pm 33\end{array}$ & $\begin{array}{l}3 \\
68 \pm 26\end{array}$ & $\begin{array}{l}23 \\
92 \pm 14\end{array}$ & $\begin{array}{l}3 \\
62 \pm 12\end{array}$ \\
\hline
\end{tabular}

Table 6 Respiratory physiological measurements of tobacco workers according to the profusion of pulmonary radiographic opacities and occurrence of antibodies

\begin{tabular}{|c|c|c|c|c|c|c|c|c|}
\hline \multirow{2}{*}{$\begin{array}{l}\begin{array}{l}\text { Profusion of pulmonary } \\
\text { opacities }\end{array} \\
<1 / 0 \text { : } \\
\text { No } \\
\text { Mean } \pm \text { SD }\end{array}$} & \multicolumn{2}{|c|}{$\begin{array}{l}\text { FVC antibodies } \\
\text { Present Absent }\end{array}$} & \multicolumn{2}{|c|}{$\begin{array}{l}\text { FEV, antibodies } \\
\text { Present Absent }\end{array}$} & \multicolumn{2}{|c|}{$\begin{array}{l}\text { MMEF antibodies } \\
\text { Present } \quad \text { Absent }\end{array}$} & \multicolumn{2}{|c|}{$D L_{C O}$ antibodies } \\
\hline & $\begin{array}{l}24 \\
96 \pm 14\end{array}$ & $\begin{array}{l}25 \\
98 \pm 10\end{array}$ & $\begin{array}{l}24 \\
94 \pm 14\end{array}$ & $\begin{array}{l}25 \\
80 \pm 8\end{array}$ & $\begin{array}{l}24 \\
97 \pm 27\end{array}$ & $\begin{array}{l}25 \\
96 \pm 29\end{array}$ & $\begin{array}{l}24 \\
96 \pm 16\end{array}$ & $\begin{array}{l}25 \\
93 \pm 13\end{array}$ \\
\hline $\begin{aligned} \geqslant & 1 / 0: \\
& \text { No } \\
& \text { Mean } \pm \text { SD }\end{aligned}$ & $\stackrel{5}{76 \pm 32}$ & $\stackrel{3}{95 \pm 6}$ & $\stackrel{5}{82 \pm 15}$ & $\stackrel{3}{91 \pm 6}$ & $\stackrel{5}{55 \pm 28}$ & $\begin{array}{l}3 \\
88 \pm 24\end{array}$ & $\begin{array}{l}5 \\
76 \pm 19\end{array}$ & $\begin{array}{l}3 \\
82 \pm 18\end{array}$ \\
\hline
\end{tabular}


Table 7 Respiratory physiological measurements of tobacco workers according to smoking habit and occurrence of antibodies

\begin{tabular}{|c|c|c|c|c|c|c|c|c|}
\hline \multirow{2}{*}{$\begin{array}{l}\text { Smoking habits } \\
\text { Non-smokers: }\end{array}$} & \multicolumn{2}{|c|}{ FVC antibodies } & \multicolumn{2}{|c|}{ FEV antibodies } & \multicolumn{2}{|c|}{$M M E F$ antibodies } & \multicolumn{2}{|c|}{$D L_{C O}$ antibodies } \\
\hline & & & & & & & & \\
\hline $\begin{array}{l}\text { No } \\
\text { Mean } \pm \text { SD }\end{array}$ & $\begin{array}{l}9 \\
95 \pm 12\end{array}$ & $\begin{array}{l}13 \\
100 \pm 10\end{array}$ & $\begin{array}{l}9 \\
95 \pm 13\end{array}$ & $\begin{array}{l}13 \\
98 \pm 11\end{array}$ & $\begin{array}{c}9 \\
96 \pm 26\end{array}$ & $\begin{array}{l}13 \\
95 \pm 25\end{array}$ & $\begin{array}{c}9 \\
97 \pm 8\end{array}$ & $\begin{array}{l}13 \\
93 \pm 8\end{array}$ \\
\hline Ex-smokers: & & 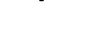 & & & & & & \\
\hline $\begin{array}{l}\text { No } \\
\text { Mean } \pm S D\end{array}$ & $10^{4} \pm 3$ & $\stackrel{5}{87 \pm 15}$ & $\begin{array}{l}4 \\
81\end{array}$ & $\stackrel{5}{100 \pm 10}$ & $\stackrel{4}{75 \pm 38}$ & $\stackrel{5}{112 \pm 13}$ & $\stackrel{4}{96 \pm 19}$ & $\stackrel{5}{97 \pm 17}$ \\
\hline Smokers: & & & & & & & & \\
\hline $\begin{array}{l}\text { No } \\
\text { Mean } \pm S D\end{array}$ & $\begin{array}{l}16 \\
93 \pm 24\end{array}$ & $\begin{array}{l}10 \\
94 \pm 11\end{array}$ & $\begin{array}{l}16 \\
97 \pm 13\end{array}$ & $\begin{array}{l}10 \\
93 \pm 16\end{array}$ & $\begin{array}{l}16 \\
91 \pm 32\end{array}$ & $\begin{array}{l}10 \\
89 \pm 35\end{array}$ & $\begin{array}{l}16 \\
90 \pm 22\end{array}$ & $\begin{array}{l}10 \\
86 \pm 13\end{array}$ \\
\hline
\end{tabular}

Table 8 Prevalence of antibodies in different exposure groups*

\begin{tabular}{|c|c|c|c|c|c|}
\hline Antibodies against & $\begin{array}{l}\text { Group } 1 \\
(n=9)\end{array}$ & $\begin{array}{l}\text { Group } 2 \\
(n=25)\end{array}$ & $\begin{array}{l}\text { Group } 3 \\
(n=13)\end{array}$ & $\begin{array}{l}\text { Group } 4 \\
(n=10)\end{array}$ & $\begin{array}{l}\text { Total } \\
(n=57)\end{array}$ \\
\hline $\begin{array}{l}\text { M faeni } \\
T \text { vulgaris } \\
\text { A fumigatus } \\
\text { A umbrosus } \\
\text { Total }\end{array}$ & $\begin{array}{l}1(11 \%) \\
1(11 \%) \\
5(56 \%) \\
0 \\
7(78 \%)\end{array}$ & $\begin{array}{c}1(4 \%) \\
1(4 \%) \\
9(36 \%) \\
2(8 \%) \\
13(52 \%)\end{array}$ & $\begin{array}{l}1(8 \%) \\
2(15 \%) \\
6(46 \%) \\
0 \\
9(69 \%)\end{array}$ & $\begin{array}{l}0 \\
3(30 \%) \\
4(40 \%) \\
0 \\
7(70 \%)\end{array}$ & $\begin{array}{r}3(5 \%) \\
7(12 \%) \\
24(42 \%) \\
2(4 \%) \\
36(63 \%)\end{array}$ \\
\hline
\end{tabular}

${ }^{*}$ Groups as in table 1.

Table 9 Presence of antibodies according to the duration of exposure

\begin{tabular}{llllll}
\hline Duration of exposure & M faeni & Th vulgaris & A fumigatus & A umbrosus & Together \\
\hline $\begin{array}{l}<10 \text { years: } \\
\text { No }=30\end{array}$ & $0(0 \%)$ & $4(13 \%)$ & $10(33 \%)$ & $0(0 \%)$ & $14(47 \%)^{*}$ \\
$\begin{array}{l}10 \text { years: } \\
\text { No }=27\end{array}$ & $3(11 \%)$ & $3(11 \%)$ & $14(52 \%)$ & $2(8 \%)$ & $22(81 \%)^{*}$ \\
\hline
\end{tabular}

${ }^{*}$ In comparison $\mathrm{p}<0.05\left(x^{2}=5.982\right)$.

smoking habits were compared with respect to antibodies and lung functions (tables 6 and 7).

\section{ANGIOTENSIN CONVERTING ENZYME}

The ACE activity was highest in exposure group 1 and lowest in exposure group 4 (table 1). Eight workers with mild diffuse lung fibrosis in chest $x$ rays $(1 / 0-1 / 1)$ had an ACE level of $26 \pm 5 \mathrm{U} / 1$, whereas the corresponding value for workers without lung fibrosis was $21 \pm 9 \mathrm{U} / \mathrm{l}$. The activity of $\mathrm{ACE}$ was slightly higher among men than women $(23 \pm 5 \mathrm{U} / \mathrm{l} v$ $20 \pm 9 \mathrm{U} / \mathrm{l})$, but the difference was not statistically significant. Smoking habits did not affect the ACE level in any group, nor was there any difference in ACE level between subjects with and without observed antibodies.

\section{ANTIBODIES}

Twenty nine of the 57 workers $(51 \%)$ had weakly positive antibodies against one or more of the microbes, and the titre was positive in 24 subjects $(42 \%)$. The prevalence of antibodies in different exposure groups is presented in table 8 . In all groups the prevalence was highest against $A$ fumigatus. A prolonged exposure seemed to be associated with an increased prevalence of antibodies (table 9).

\section{CLINICAL FINDINGS OF SUBJECTS WITH WORK RELATED RESPIRATORY SYMPTOMS}

Weakly postive antibodies against farmer's lung microbes were found in 11 of the 15 workers $(73 \%)$ with work related respiratory symptoms, and positive antibodies in eight subjects $(53 \%)$. Chest $x$ ray films taken of the 15 patients with symptoms showed mild diffuse fibrosis $(\geqslant 1 / 0)$ in five cases $(33 \%)$ and a $0 / 1$ finding in three cases $(20 \%)$. DL $L_{C O}$ was decreased $(<80 \%$ of the predicted) in four of those 15 workers $(27 \%)$, as were restriction (FVC $80 \%$ of the predicted) and obstruction (FEV\% more than $13 \%$ for men and $11 \%$ for women below the predicted) for three subjects $(20 \%)$. MMEF was decreased $(<70 \%$ of the predicted) in nine of the 15 workers $(60 \%)$; two of the nine were non-smokers. 
Four of the 15 workers with work related symptoms showed neither impaired lung function nor mild diffuse lung fibrosis $(1 / 0-1 / 1)$. In summary three clinical cases of typical allergic alveolitis were found among the workers studied and they will be described in a later report.

\section{Discussion}

A conspicuous prevalence of work related symptoms compatible with extrinsic allergic alveolitis, lung fibrosis, and decreased diffusion capacity was found among the 57 workers engaged in producing tobacco. Fifteen $(26 \%)$ reported symptoms that they associated with the work environment. Diffuse lung fibrosis was found in eight workers; five of them belonging to the symptomatic group. Thus 33\% (5/ 15) of those experiencing work related symptoms showed fibrotic radiographic changes, four $(27 \%)$ had a decreased diffusion capacity, whereas only four had a normal lung function and no radiographic fibrosis.

An association between smoking and some of the findings cannot be excluded. Twelve of 15 symptomatic workers were smokers. Mild fibrosis may be related to smoking ${ }^{14}$ and an impaired ventilationperfusion relationship in smokers with chronic bronchitis may be manifested as a decreased diffusion capacity. Some subjects, however, presented with diffuse fibrosis and a decreased diffusion capacity without having any symptoms of chronic bronchitis.

The clustering of symptoms and signs compatible with extrinsic allergic alveolitis (EAA) in this comparatively small group of workers focuses interest on possible exposures in the working environment. It is also worth noting that 11 of the 15 symptomatic workers had been working in the two most dusty operations (categories 1-2). Hygienic measurements performed on a single occasion showed comparatively small numbers of spores of $T h$ vulgaris and $A$ fumigatus; these concentrations were lower than those generally associated with acute exacerbations of EAA. Nevertheless, the insidious development of EAA may result from prolonged exposure to low concentrations of the causal agents. ${ }^{2}$ The intensity of a previous exposure cannot be retrospectively assessed; however, the high prevalence of precipitating antibodies indicates that it has been strong enough to elicit antibody production in a high proportion of the studied workers. The prevalence of antibodies was significantly higher among workers with radiographic signs of fibrosis and among the symptomatic workers (table 3 ) than among other workers. Thus the precipitating antibodies appear to be associated with the development of symptoms and fibrosis. These observations 'seem to favour EAA as the explanation for the findings. The interpretation is further supported by two clinical observations: two subjects with antibodies in their sera and with diffuse lung fibrosis in the chest radiograph were subjected to a workplace provocation. At work, the diffusion capacities were $60-70 \%$ of the predicted values, whereas during an absence of three to four weeks from work the diffusion capacity improved to about $80 \%$, remaining at that level so long as the workers just stayed away from exposure. On returning to work the diffusion capacity returned in one month to the starting level. Furthermore, three cases of typical EAA according to accepted criteria ${ }^{212}$ were found and will be reported in detail elsewhere. It is well known that the numbers of spores in different series of imported raw tobacco vary extensively. The single measurements of spore concentrations are, therefore, unlikely to reflect the true exposure over the past 20 years.

In conclusion, the results of the present study suggest that spores from different moulds in tobacco manufacturing may have induced EAA which may pass unnoticed unless specially looked for. The results are derived from one comparatively small tobacco manufacturing plant but it would seem worth while to study the extent of the problem in other plants in various countries.

We are especially indebted to Finnish Tobacco Ltd for their valuable help throughout this work. We also wish to extend our appreciation to the workers who participated in the study, to Ms Pirjo Fahlström for help in statistical treatment of the data, and to Ms Irma Saari and Ms Tuula Kajonen for typing the manuscript. We also thank the laboratory personnel for their skilful technical aid. The English Centre, Helsinki, revised the English of the text.

\section{References}

' Pepys J. Hypersensitivity diseases of the lungs due to fungi and organic dusts. Monographs in allergy vol 4. Basel: S Karger, 1969.

2 Parkes RW.Occupational lung disorders. London: Butterworth, $1982 ; 359-414$.

${ }^{3}$ Gregory PH, Lacey ME. Mycological examination of dust from mouldy hay associated with farmer's lung disease. J Gen Microbiol 1963;30:75--88

${ }^{4}$ McMillan GHG, Pethybridge RJ, Sheers G. Effect of smoking on attack rates of pulmonary and pleural lesions related to exposure to asbestos dust. Br J Ind Med 1980;37:268-72.

s Medical Research Council's Committee on the aetiology of chronic bronchitis. Standardised questionnaire on respiratory symptoms. Br Med J 1960;ii:1665.

- Harris PG. Clinical signs. In: Bogovsky P, ed. Biological effects on asbestos. Lyon: International Agency for Research on Cancer, 1973:19-24.

7 Zitting A, Huuskonen MS, Alanko K, Mattsson T. Radiographic 
and physiological findings in patients with asbestosis. Scand $J$ Work Environ Health 1978;4:275-83.

${ }^{8}$ International Labor Office. ILO international classification of radiographs of pneumoconioses. Geneva: ILO, 1980: 1-48. (Occupational Safety and Health Series No 22 (rev)).

${ }^{9}$ Cotes JE. Lung function. Assessment and application in medicine. 3rd ed. Oxford: Blackwell Scientific Publications, 1975:619.

${ }^{10}$ Chiknas SG. A liquid chromatography assisted assay for angiotensin-converting enzyme (peptidyl dipeptidase) in serum. Clin Chem 1979;7:1259-63.
"Lieberman J. Elevation of serum angiotensin-converting enzyme (ACE) level in sarkoidosis, Am J Med 1975;59:365-72.

12 Terho E. Microbiological and serological studies on farmer's lung disease. Kuopio: Kuopio University, 1978. (Academic dissertation.)

${ }^{13}$ Ojanen TH, Katila M-L, Mäntyjärvi RA. The use of enzymelinked immunosorbent assay (ELISA) in the diagnosis of farmer's lung. Allergy 1980;35:537-42.

14 Weiss W. Cigarette smoking and diffuse pulmonary fibrosis. Am Rev Respir Dis 1969;99:67-75.

\section{The November 1983 issue}

\section{THE NOVEMBER 1983 ISSUE CONTAINS THE FOLLOWING PAPERS}

Dust exposure and mortality in an American chrysotile textile plant A D McDONALD, J S FRY, A J WOOLLEY, AND J C MCDONALD

Dust exposure and mortality in an American factory using chrysotile, amosite, and crocidolite in mainly textile manufacture A D McDONALD, J S FRY, A J WOOLLEY, AND J C McDONALD

Fibre type and concentration in the lungs of workers in an asbestos cement factory B GYLSETH, G MOWÉ, AND A WANNAG

Tobacco consumption and asbestos exposure in patients with lung cancer: a three year prospective study G HILLERDAL, EVA KARLÉN, AND T ÅBERG

Lung cancer associated with chloromethyl methyl ether manufacture: an investigation at two factories in the United Kingdom R I McCALLUM, V WOOLLEY, AND A PETRIE

\section{A brief history of scrotal cancer H A WALDRON}

Effects of lead exposure on peripheral nerve in the cynomolgus monkey D A PURSER, K R BERRILL, AND $S$ K MAJEED

Effects of occupational exposure to elemental mercury on short term memory P J SMITH, G D LANGOLF, AND J GOLDBERG

Cadmium in blood and urine related to present and past exposure. A study of workers in an alkaline battery factory EJDA HASSLER, B LIND, AND M PISCATOR

Vibration syndrome and vibration in pedestal grinding J STARCK, M FÄRKKILÄ, S AATOLA, I PYYKKÖ, AND O KORHONEN
Blood pressure, flow, and peripheral resistance of digital arteries in vibration syndrome $M$ FUTATSUKA, I PYYKKÖ, M FÄRKKILÄ, O KORHONEN, AND J P STARCK

Allergy to laboratory animals: a retrospective and a prospective study G E DAVIES, AUDREY $V$ THOMPSON, Z NIEWOLA, G E BURROWS, E L TEASDALE, DOROTHY J BIRD, AND DOROTHY A PHILLIPS

Industrial gassing poisonings due to trichlorethylene, perchlorethylene, and 1-1-1 trichloroethane, 1961-80 T B McCARTHY, AND R D JONES

Reversibility of skeletal fluorosis P GRANDJEAN AND G THOMSEN

Interference with the pacemakers of two workers at electricity substations G S BUTROUS, R S BEXTON, D G BARTON, J C MALE, AND A J CAMM

Antipyrine clearance during experimental and occupational exposure to toluene M DøSsING, J BAELUM, AND G R LUNDQVIST

Urinary hippuric acid and orthocresol excretion in man during experimental exposure to toluene $M$ DøSSING, J BAELUM, S H HANSEN, G LUNDQVIST, AND N T ANDERSEN

Book Review

Notice

Information section

Index to volume

Copies are still available and may be obtained from the PUBLISHING MANAGER, BRITISH MEDICAL ASSOCIATION, TAVISTOCK SQUARE, LONDON WC1H 9JR, price $£ 4 \cdot 25$ (USA $\$ 9 \cdot 20$ ), including postage 